\title{
Development of Mobile Media "GeMBul" in Science Learning: The Validity and Reliability Study
}

\author{
Windy Kasmita ${ }^{1}$, Ida Hamidah ${ }^{2}$, Diana Rochintaniawati ${ }^{3}$ \\ $\left\{\right.$ $\left\{{ }^{1}\right.$ windykasmita@upi.edu, ${ }^{2}$ idahamidah@upi.edu, ${ }^{3}$ diana_rochintaniawati@upi.edu $\}$ \\ ${ }^{1,2,3}$ Natural Science Postgraduate Program, Universitas Pendidikan Indonesia
}

\begin{abstract}
The development of technology 4.0 affects learning and teaching in schools, especially with the COVID-19 pandemic, which requires teachers and students to use technology. This study aims to develop mobile media on solar and lunar eclipse material, abbreviated as "GeMBul," which can assist teachers in teaching concepts. Students can repeat learning materials anytime and anywhere. The development of mobile media "GeMBul" was developed using the ADDIE model (analysis, design, development, implementation, and evaluation). Validation was carried out by three material experts and one media expert with 78.33 and 76. The mobile media "GeMBul" was valid/feasible to use in science learning. The limited trial of mobile media "GeMBul" to students and teachers obtained 91 and 94 with excellent categories. Reliability data were obtained from a multiple-choice test of conceptual understanding and technological literacy as many as 22 questions to 75 junior high school students in Surabaya. The reliability results stated that the test was declared reliable to measure students' conceptual understanding and literacy with high criteria. The responses of students and teachers to the "GeMBul" application in terms of the practicality of using the "GeMBul" application obtained data that students and teachers stated that the "GeMBul" application was efficient to use in science learning with scores of 83.96 and 90.
\end{abstract}

Keywords: mobile media, mobile technology, conceptual understanding, technology literacy, science learning

\section{Introduction}

The rapid development of technology should be a place for teachers and students to improve the quality of education. Children need to be encouraged to be ready to acquire lifelong knowledge and skills in the 21st century [1]. Thus, the integration of technology becomes a must in the learning process. Learning that uses technology assistance in learning has various benefits for students ranging from involvement, comfort, convenience, achievement, and satisfaction [2]. One technology that almost everyone has is mobile. Mobile technology has entered every activity carried out by students or the community. The use of mobile has developed so that the functions of mobile technology are increasingly being used effectively. Mobile technology can be accessed anytime and anywhere. Mobile technology has also entered the realm of education, where the use of mobile technology can develop various ways of student learning both at school, at home, and in the community, interacting with others, sharing information and views, absorbing information from multiple sources, increasing student understanding of concepts, and achievement. Academic students in the learning process [3][4][5]. 
The use of mobile technology in science learning will also increase students' technological literacy as a form of skill development in the 21 st century. One of the 21 st-century skills that students must possess is the ability of students to access and use technology in the learning process. Technological literacy is seen as very important considering the increasingly rapid technological developments [6]. Technological developments will affect students' technological literacy in learning, especially during the Corona Virus Disease 2019 (Covid-19) pandemic where face-to-face learning cannot be carried out, so students and teachers are required to be able to carry out technology-based learning (e-learning).

Technological literacy is the ability to use technology effectively in completing required learning tasks [7]. Rapid technological developments will need students to have good technical literacy skills. Therefore, students' literacy skills must be maintained to help achieve learning objectives. Students' specialized literacy skills will lead students to have the ability to adapt, adapt, find and evaluate technology that can be used to achieve learning goals [8].

One way to integrate mobile technology in learning is to apply the learning media needed to help today's learning process, especially during the COVID-19 pandemic. Mobile technologybased media is one of the best solutions considering the very high use of mobile technology among students and teachers. Mobile media in learning can help teachers explain science concepts and improve students' conceptual understanding and technological literacy.

One way to integrate mobile technology in learning is to apply the learning media needed to help today's learning process, especially during the COVID-19 pandemic. Mobile technologybased media is one of the best solutions considering the very high use of mobile technology among students and teachers. Mobile media in learning can help teachers explain science concepts and improve students' conceptual understanding and technological literacy.

\section{Research Methods}

This study uses the ADDIE development model, namely analysis, design, development, implementation, and evaluation. The model is a more systematic, simple, and interactive process in which each phase integrates and synergizes with each other $[9,10]$. This article is limited to the development stage and the validity and reliability tests of students' conceptual understanding and technological literacy. The subjects of this study were 7 th-grade junior high school students in Surabaya as many as 75 students. Furthermore, validation is carried out by experts by validating the content/material and media from the mobile media "GeMBul". The data were obtained from the results of the validity and comments given by material and media experts on the "GeMBul" application using a media and material validation questionnaire. The experts who carried out the validity of the "GeMBul" application consisted of 3 material experts and 1 media expert. Reliability data were obtained from the multiple-choice test of conceptual understanding and technological literacy as many as 22 questions and the data were analyzed using SPSS version 26. 


\section{Results and Discussion}

The development of the mobile media "GeMBul" was carried out using the ADDIE development model in science learning at the junior high school level to improve students' conceptual understanding and technological literacy. In this study, it was limited to the development stage because the researchers only looked at the validity of the "GeMBul" application in science learning and the consistency of the conceptual understanding test and technological literacy in measuring students' understanding and literacy levels of the material provided and seeing the responses of teachers and students related to the practicality of using the application. "gamble" in science learning.

\subsection{Analysis Stage}

The mobile media "GeMBul," which was developed in this study, raised the solar system's subject matter, sub-material of solar and lunar eclipses. Development of mobile media "GeMBul" to improve students' understanding of concepts and technological literacy. The portable media "GeMBul" contains easy-to-access content, is easy to use, and can be used in the form of games that can be played individually and in groups. The development of "GeMBul" mobile media analyzes the curriculum, materials, and student characteristics.

\subsubsection{Curriculum Analysis Results}

The curriculum used in Indonesia is the 2013 curriculum. Based on the science subject syllabus data, there are core competencies and essential competencies selected in the study, as shown in table 1 .

Table 1. Core Competencies and Basic Competencies for Class VII Science Learning regarding Solar and

\begin{tabular}{ll}
\hline \multicolumn{1}{c}{ Core Competencies } & \multicolumn{1}{c}{ Basic Competencies } \\
\hline 3. Understanding knowledge (factual, conceptual, and & $\begin{array}{l}\text { 3.11 Understanding the solar system, the } \\
\text { rotation and revolution of the earth and } \\
\text { poon, and their impact on life on earth }\end{array}$ \\
art, culture related to visible phenomena and events & $\begin{array}{l}\text { 4.11 Presenting works on the impact of } \\
\text { 4. Trying, processing, and presenting in the concrete realm } \\
\text { (using, parsing, assembling, modifying, and helping) and } \\
\text { the abstract realm (writing, reading, counting, drawing, and } \\
\text { composing) according to what is learned in school and }\end{array}$ \\
$\begin{array}{l}\text { moon for life on earth based on } \\
\text { other sources in the same perspective. /theory }\end{array}$ & \begin{tabular}{l} 
sources. \\
\hline
\end{tabular}
\end{tabular}

\subsubsection{Material Analysis}

Based on the core competencies and essential competencies above, they can be broken down into several main topics: the planets, the concept of a solar eclipse, lunar eclipse, telescope, and tides. The primary materials that have been described are made indicators to be achieved, 
which aim to focus research on the indicators to be completed in the manufacture of mobile media "GeMBul." The details of the indicators of the selected subject matter can be seen in table 2.

Table 2. Basic Competencies and Indicators on the Concept of Solar and Lunar Eclipse

\begin{tabular}{|c|c|}
\hline Basic Competencies & Indicators \\
\hline $\begin{array}{l}3.11 \text { Understanding the solar system, } \\
\text { the rotation and revolution of the earth } \\
\text { and moon, and their impact on life on } \\
\text { earth } \\
4.11 \text { Presenting works on the impact } \\
\text { of the rotation and revolution of the } \\
\text { earth and moon for life on earth based } \\
\text { on observations or searches for } \\
\text { information sources. }\end{array}$ & $\begin{array}{l}\text { 1. Classify the characteristics of the planets in the solar } \\
\text { system } \\
\text { 2. Explain the concept of eclipse } \\
\text { 3. Explain the process of the total, ring, and partial solar } \\
\text { eclipses } \\
\text { 4. Explain the process of accommodation, partial and } \\
\text { 5enumbral lunar eclipses } \\
\text { 6. Explain about telescope } \\
\text { 7. Explain the effects of solar and lunar eclipses }\end{array}$ \\
\hline
\end{tabular}

Based on the KD and indicators above, the content/material in the mobile media "GeMBul" is created, improving students' conceptual understanding and literacy in science concepts. The material/content in educational media must pay attention to the content provided to students so that it is exciting and can be played by students [11].

\subsubsection{Analysis of Student Characteristics}

Analysis of student characteristics was carried out by interviewing via WhatsApp (WA) with teachers in the classroom. Based on the results of interviews obtained, in learning, students tend to be passive, only listen to the teacher's explanation, lack motivation in online learning. Internet signal is also one of the reasons why students sometimes don't attend lessons while online. Besides that, the teacher also explained the effect of cell phones on students because, during the pandemic, students studied more online and played more games than at home. The teacher also found that students answered the questions correctly when the individual material exams were conducted online. But when the school's midterm exams held offline exams, it was found that there were still many students who did not understand the material presented. The teacher suspects this is because students can copy answers via the Internet, not the results of students' understanding.

In addition, students' character at the seventh grade of junior high school is a transitional age where students are more likely to like to play and practice hands-on. The development of technology also makes teenagers dependent on the Internet and online games [12]. Students' varied learning styles are also a challenge for teachers in conveying solar and lunar eclipses both online and online the tendency of students to learn when learning is considered attractive by them.

\subsection{Design Stage}

The mobile media "GeMBul" developed is a game-based media that is expected to increase students' understanding of concepts and technological literacy. Previous research has shown that 
game-based learning can increase motivation, student engagement [13], effectively used in education [14], and improve students' learning attitudes, achievement, and self-confidence [15]. The developed mobile media "GeMBul" also contains evaluations that can measure students' conceptual understanding. According to [16], it is essential to include assessment in game-based learning to show the achievements in the teaching. The "GeMBul" mobile media design made by researchers can be seen in Figure 1.

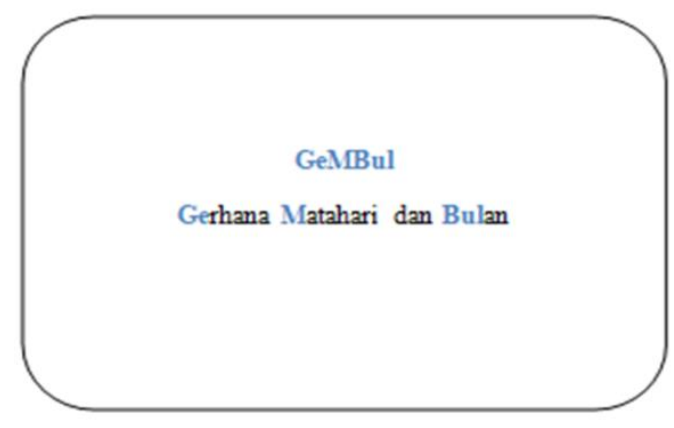

(a)

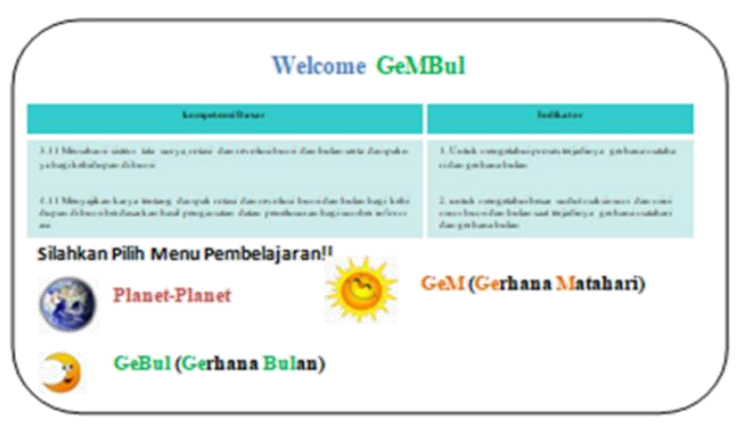

(b)

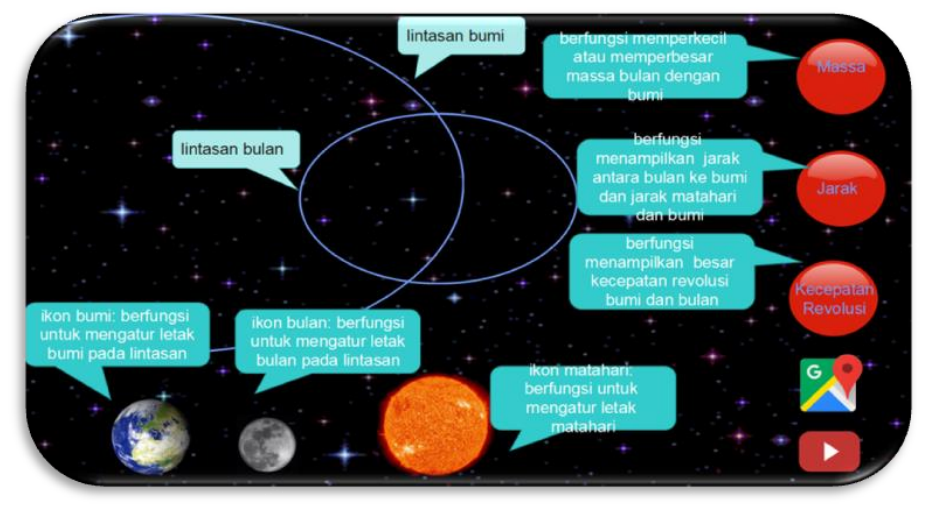

(c)

Fig. 1. (a) "GeMBul" cover design (b) KD Design and Indicators and Learning menus (c) Key Functions on "GemBul" media

\subsection{Development Stage}

Development is carried out according to the design carried out. However, in the process, the researchers made changes to the layout and background of the "GeMBul" application to make it look attractive to students. The results of the development of the "GeMBul" application media can be seen in Figure 2. 


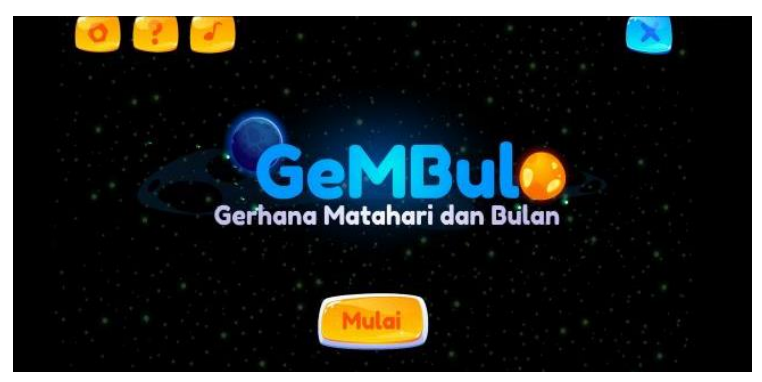

(a)

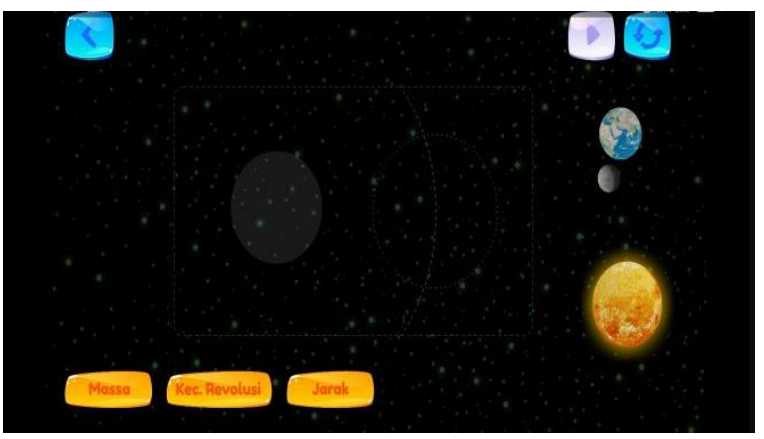

(c)

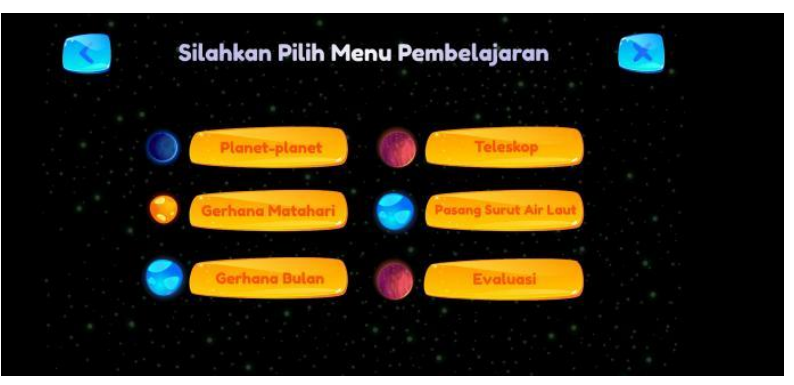

(b)

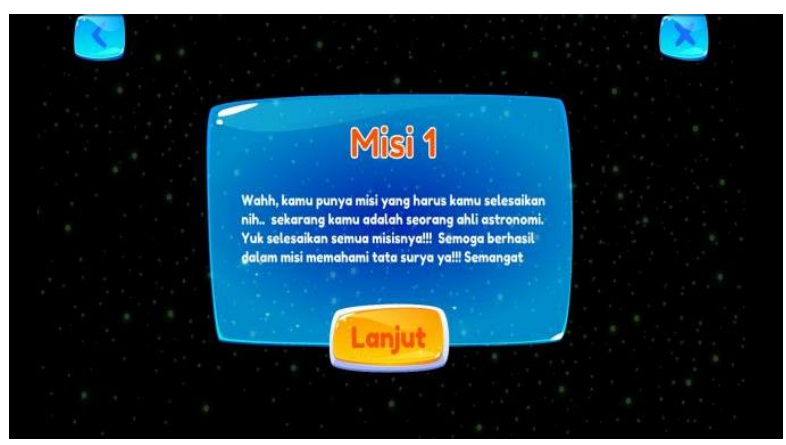

(d)

Fig. 2. (a) cover of "GeMBul” (b) Learning Menu (c) Room view of solar and lunar eclipses (d) display of mission instructions that students must do.

\subsection{Validation of "GeMBul" mobile media by experts}

The "GeMBul" mobile media created and tested and has passed the repair and refinement stage is validated by material and media experts. The "GeMBul" media was validated by three material experts and one media expert to be used in learning. The results of the validation of the experts can be seen in table 3. and table 4.

\subsubsection{Material expert validation results}

Three validators carried out material expert validation with the results of the validators being seen in table 3 .

Table 3. Material Expert Validation Results

\begin{tabular}{llcc}
\hline No & Name Validator & Eligibility Percentage $(\%)$ & Criteria \\
\hline 1. & Validator 1 & 75 & Valid \\
2. & Validator 2 & 86 & Very Valid \\
3. & Validator 3 & 74 & Valid \\
Rata-rata & $\mathbf{7 8 . 3 3}$ & Valid \\
\hline
\end{tabular}

Based on the results of material expert validation, it was concluded that the content contained in the "GeMBul" application was suitable for use by users. 


\subsubsection{Media Expert Validation Results}

One validator carried out media expert validation with the results of the validator can be seen in table 4.

Table 4. Media Expert Validation Results

\begin{tabular}{llcc}
\hline No & Name Validator & Eligibility Percentage (\%) & Criteria \\
\hline 1. & Validator 1 & 76 & Valid \\
\hline
\end{tabular}

Based on the results of media expert validation, it was concluded that the "GeMBul" application media was suitable for use by users.

\subsection{Reliability of mobile media "GeMBul."}

The development of the mobile media "GeMBul" is carried out to improve students' conceptual understanding and technological literacy. Concept understanding and specialized literacy tests were made to measure students' abilities before and after using the mobile media "GeMBul" in science learning. Before the "GeMBul" mobile media reliability test was carried out, an examination of the difficulty level of the questions and the differentiating power of the questions was conducted. The story of difficulty test is carried out to see the proportion of inquiries made in complex, medium, and accessible categories. At the same time, the Distinguishing Power or the discrimination index to see and distinguish between the intelligent group and the group that is somewhat lacking with the decision criteria presented in the table. The analysis of the IBM SPSS version 26 differentiating power and the level of difficulty of the technology literacy test and understanding concepts can be seen in Tables 5 and 6 .

Table 5. Criteria for Question Difficulty Level [17]

\begin{tabular}{cc}
\hline Range Koefisien & Kriteria \\
\hline $\mathbf{0 , 0 0 - 0 , 3 0}$ & Hard \\
$\mathbf{0 , 3 1 - 0 , 7 0}$ & Medium \\
$\mathbf{0 , 7 1 - 1 , 0 0}$ & Easy \\
& \\
Tabel 6. Discriminating Power Criteria [17] \\
\hline Range Koefisien & Kriteria \\
& \\
\hline $\mathbf{0 , 0 0 - 0 , 2 0}$ & Ugly \\
$\mathbf{0 , 2 1 - 0 , 4 0}$ & Enough \\
$\mathbf{0 , 4 1 - 0 , 7 0}$ & Good \\
$\mathbf{0 , 7 1 - 1 , 0 0}$ & Very good \\
\hline
\end{tabular}

Table 7. Result of SPSS Results of Discriminating Power and Difficulty Level of Technology Literacy Test and Concept Understanding

\begin{tabular}{llll} 
No & Discriminating Power & Difficulty Level & Information \\
\hline
\end{tabular}




\begin{tabular}{|c|c|c|c|c|c|}
\hline Test & Value & Criteria & Value & Criteria & \\
\hline \multicolumn{6}{|c|}{ Technology Literacy } \\
\hline 1. & .306 & Enough & .82 & Easy & Revised, used \\
\hline 2. & .257 & Enough & .87 & Easy & Revised, used \\
\hline 3. & .385 & Enough & .71 & Easy & Revised, used \\
\hline 4. & .347 & Enough & .83 & Easy & Revised, used \\
\hline 5. & .168 & Ugly & .47 & Medium & Not Used \\
\hline 6. & .332 & Enough & .50 & Medium & Revised, used \\
\hline 7. & .423 & Good & .59 & Medium & Used \\
\hline 8. & .305 & Enough & .62 & Medium & Revised, used \\
\hline 9. & -.075 & Ugly & .38 & Medium & Not Used \\
\hline 10. & .396 & Enough & .55 & Medium & Revised, used \\
\hline 11. & .339 & Enough & .45 & Medium & Revised, used \\
\hline 12. & .478 & Good & .76 & Easy & Used \\
\hline \multicolumn{6}{|c|}{ Concept Understanding } \\
\hline 22. & .360 & Enough & .50 & Medium & Revised, used \\
\hline 23. & .523 & Good & .68 & Medium & Used \\
\hline 24. & .231 & Enough & .43 & Medium & Revised, used \\
\hline 25. & .218 & Enough & .78 & Easy & Revised, used \\
\hline 26. & .399 & Enough & .80 & Easy & Revised, used \\
\hline 27. & .364 & Enough & .58 & Medium & Revised, used \\
\hline 28. & .422 & Good & .59 & Medium & Used \\
\hline 29. & .442 & Good & .46 & Medium & Used \\
\hline 30. & .572 & Good & .55 & Medium & Used \\
\hline 31. & .246 & Enough & .37 & Medium & Revised, used \\
\hline
\end{tabular}


Based on table 7, information is obtained that the test results of technological literacy questions are 12 questions; two questions cannot measure students' technological literacy because they are in the wrong and easy category. The technological literacy questions used for this research are ten questions. Furthermore, ten questions on the conceptual understanding test can measure the students' overall conceptual understanding ability. Moreover, the instrument test results are processed by obtaining a reliability index and then interpreted. The interpretation of the reliability index can be made based on the following table 8 .

Table 8.Reliability Criteria[17]

\begin{tabular}{cc}
\hline Coefficient Range & Criteria \\
\hline $\mathbf{0 , 8 1 - 1 , 0 0}$ & Very high \\
$\mathbf{0 , 6 1 - 0 , 8 0}$ & High \\
$\mathbf{0 , 4 1 - 0 , 6 0}$ & Enough / Moderate \\
$\mathbf{0 , 2 1 - 0 , 4 0}$ & Low \\
$\mathbf{0 , 0 0 - 0 , 2 0}$ & Very low \\
\hline
\end{tabular}

An instrument is reliable if count $>_{\text {table }}$ at a significance level of 5\% [17]. The results of the reliability analysis of conceptual understanding and technological literacy are presented in table 9.

Table 9. Reliability Results of Concept Understanding and Technology Literacy Tests Tes Tes Reliability Statistics

\begin{tabular}{lcccc} 
& Cronbach's Alpha & N of Items & Conclusion & Criteria \\
Concept Understanding & .658 & 12 & Reliable & Tinggi \\
Technological Literacy & .717 & 10 & Reliable & Tinggi \\
\hline
\end{tabular}

Based on table 9, it can be concluded that the student's concept understanding and technological literacy test questions are reliable and suitable to be used to measure students' conceptual understanding and technical literacy skills.

\subsection{Teacher and Student Responses}

Student and Teacher Responses to the Practicality of Mobile Media "GeMBul," which was developed in science learning, can be seen from the questionnaires that the researchers distributed to students and teachers. The practicality of the generated mobile media "GeMBul" can be seen in tables 10 and 11 .

Table 10. Results of Student and Teacher Responses to the Practicality of "GeMBul" Mobile Media

\begin{tabular}{ccccccc}
\hline Assessment Aspect & \multicolumn{3}{c}{ Student } & \multicolumn{2}{c}{ Teacher } \\
\cline { 2 - 5 } & Score & Average & Criteria & Score & Average & Criteria \\
\hline
\end{tabular}




\begin{tabular}{|c|c|c|c|c|c|c|}
\hline & \multicolumn{3}{|c|}{$(\%)$} & \multicolumn{3}{|c|}{$(\%)$} \\
\hline $\begin{array}{l}\text { Ease of use of mobile media "GeMBul" in } \\
\text { learning }\end{array}$ & 74 & 87.06 & $\begin{array}{l}\text { Very } \\
\text { Practical }\end{array}$ & 5 & 100 & $\begin{array}{l}\text { Very } \\
\text { Practical }\end{array}$ \\
\hline $\begin{array}{l}\text { Increase student interest and motivation } \\
\text { when used in individual and classroom } \\
\text { learning }\end{array}$ & 61 & 71.76 & Practical & 5 & 100 & $\begin{array}{l}\text { Very } \\
\text { Practical }\end{array}$ \\
\hline $\begin{array}{l}\text { It can be used for individual study by } \\
\text { students }\end{array}$ & 65 & 76.47 & Practical & 4 & 80 & Practical \\
\hline It can be used as a teaching aid for teachers & 63 & 74.12 & Practical & 4 & 80 & Practical \\
\hline $\begin{array}{l}\text { Helping students understand the concept of } \\
\text { solar and lunar eclipses and their impact on } \\
\text { the earth. }\end{array}$ & 73 & 85.88 & $\begin{array}{l}\text { Very } \\
\text { Practical }\end{array}$ & 5 & 100 & $\begin{array}{l}\text { Very } \\
\text { Practical }\end{array}$ \\
\hline $\begin{array}{l}\text { "GeMBul" media which was developed } \\
\text { according to the characteristics of class VII } \\
\text { SMP students }\end{array}$ & 67 & 78.82 & Practical & 4 & 80 & Practical \\
\hline
\end{tabular}

The practicality of mobile media "GeMBul" is to see the usefulness of using mobile media "GeMBul" in science learning for class VII. Suitability was analyzed using the average score of the questionnaire distributed to 17 students and one teacher of 83.96 and 90 with a convenient category ( $\mathrm{V}>80$ ). Judging from the comparison of each aspect of the assessment to the teacher, namely the ease of using mobile media "GeMBul" in learning of 87.06 with efficient criteria, the element of increasing student interest and motivation when used in learning both individually and in class is 71.76 with practical measures, the papacy element is used for individual learning by students is 76.47 with helpful categories, aspects that can be used as teaching aids for teachers are 74.12 with practical criteria, aspects of Assisting students in understanding the concept of solar and lunar eclipses and their impact on the earth is 85.88 with efficient measures and media factors "GeMBul" which was developed according to the characteristics of the seventh-grade junior high school students of 78.82 with practical actions. Based on the results of practicality carried out on students and teachers, it can be concluded that the media developed is very practical to be used by students and teachers.

Mobile media "GeMBul" can help increase students' interest and motivation when used in individual learning and in the classroom to get responses from students that can increase student interest and motivation. This can be seen from the comments given by students in the distributed questionnaires. The results of previous studies stated that implementing a mobile app can increase student motivation in learning, namely research conducted by [18][19][20][21]. Mobile media "GeMBul" can be used for individual learning by students getting responses from students and teachers that it is practical to operate both individually. The portable media "GeMBul" development was compiled and developed to be used separately or in groups. The design used by the "GeMBul" media car, which can be used offline, can support students to study independently at home and can access learning materials anytime and anywhere [22], which are not limited by space and networks. Internet. In line with the opinion [23], said that android-based learning can facilitate students who not only learn with content quickly but can also improve students' mobile learning performance, such as problem-based learning, knowledge construction tools (e.g., concept maps), discussion issue-based, collaborative learning, inquiry-based learning design, project-based learning, peer-assessment strategies, and digital storytelling. 
Furthermore, it can be used as a teaching aid for teachers to get an efficient response used by teachers in learning. This means both teachers and students say that the mobile media "GeMBul" can be a choice of android-based media that can be used in teacher teaching in improving student learning outcomes. This is in line with the opinion [24], which says that teachers can use mobile technology to facilitate the development and practice of student skills. So that not only can teachers benefit from mobile technology, but students can also develop their skills and knowledge. "GeMBul" mobile media can also help students understand the concept of solar and lunar eclipses and their impact on the earth, getting responses from students and teachers that students gain a better understanding after using. "GeMBul" mobile media. Finally, the "GeMBul" media was developed according to the characteristics of the seventh-grade junior high school students who received responses from students and teachers who stated that the "GeMBul" media agreed that the "GeMBul" mobile media was under the characteristics of students. Before developing the mobile media 'GeMBul', researchers had analyzed the factors of junior high school students so that their mobiles were designed according to the characteristics of students so that they could facilitate the development and abilities of students.

\section{Conclusion}

Based on the validity, reliability, and questionnaire responses of students and teachers to the mobile media "GeMBul" in science learning, it is concluded that the portable media "GeMBul" is valid, reliable, and practical to use in education. With the ease of using "GeMBul" mobile media in science learning, most students and teachers believe that using "GeMBul" mobile media is efficient to use. Students and teachers argue that the menus and buttons contained in the media provide convenience for students and teachers in accessing learning materials included in the "GeMBul" application. In addition, the "GeMBul" application can be a choice of educational games in learning that can increase students' enthusiasm for learning. Based on the explanation above, the researcher can recommend that the mobile media "GeMBul" can be a choice of mobile media that can be used by teachers and students in improving students' conceptual understanding and technological literacy. The portable media "GeMBul" has the advantage that it can be accessed anytime and anywhere without an internet network for all Android smartphones. Further research can develop mobile media for other learning materials. Mobile media can be developed based on Android or iOS and based on 3D so that it is easier for students to understand concepts.

Acknowledgment. The author would like to thank the Education Fund Management Institute (LPDP) for providing financial support in carrying out research conducted by researchers. 


\section{References}

[1] Ejikeme AN, Okpala HN. Promoting Children's learning through technology literacy: challenges to school librarians in the 21st century. Educ Inf Technol. 2017;22(3):1163-77.

[2] Morris NP, Lambe J, Ciccone J, Swinnerton B. Mobile technology: students perceived benefits of learning neuroanatomy. J Comput Assist Learn. 2016;32(5):430-42.

[3] Han I, Shin WS. The use of a mobile learning management system and academic achievement of online students. Comput Educ. 2016;102:79-89.

[4] Schmid R, Petko D. Does the use of educational technology in personalized learning environments correlate with self-reported digital skills and beliefs of secondary-school students? Comput Educ. 2019;136:75-86.

[5] Williams KM, Stafford RE, Corliss SB, Reilly ED. Examining student characteristics, goals, and engagement in Massive Open Online Courses. Comput Educ. 2018;126:433-42.

[6] Retnowati E, Jerusalem MA, Sugiyarto K. Innovative Teaching and Learning Methods in Educational Systems: Proceedings of the International Conference on Teacher Education and Professional Development (INCOTEPD 2018), October 28, 2018, Yogyakarta, Indonesia. Routledge; 2019.

[7] Davies RS. Understanding technology literacy: A framework for evaluating educational technology integration. TechTrends. 2011;55(5):45.

[8] Hansen JW. To change perceptions of technology programs. J Technol Stud. 2003;29(2):16-9.

[9] Molenda M. In search of the elusive ADDIE model. Perform Improv. 2015;54(2):40-2.

[10] Aldoobie N. ADDIE model. Am Int J Contemp Res. 2015;5(6):68-72.

[11] Delima R, Arianti NK, Pramudyawardani B. Identifikasi kebutuhan pengguna untuk aplikasi permainan edukasi bagi anak usia 4 sampai 6 tahun. J Tek Inform dan Sist Inf. 2015;1(1).

[12] Andrianto A, Zahra DN, ... Pola Komunikasi Orang Tua dengan Anak terhadap Ketergantungan Media Internet di BTN Gowa Lestari Batangkaluku. ... J Progr Stud ... [Internet]. 2021;7(2):34-43. Available from: https://jurnal.stitnualhikmah.ac.id/index.php/seling/article/view/724

[13] Ghergulescu I, Muntean CH. Measurement and analysis of learner's motivation in game-based elearning. In: Assessment in game-based learning. Springer; 2012. p. 355-78.

[14] Ethel S, Jamet E. Digital game-based learning: Impact of instructions and feedback on motivation and learning effectiveness. Comput Educ. 2013;67:156-67.

[15] Sung H-Y, Hwang G-J. A collaborative game-based learning approach to improving students' learning performance in science courses. Comput Educ. 2013;63:43-51.

[16] El Mawas N, Tal I, Moldovan AN, Bogusevschi D, Andrews J, Muntean GM, et al. Investigating the impact of an adventure-based 3D solar system game on primary school learning process. Knowl Manag E-Learning. 2020;12(2):165-90.

[17] Arikunto S. Dasar-dasar evaluasi pendidikan edisi 2. Jakarta Bumi Aksara. 2012;

[18] Elvish MM, Ghani NA, Shuib L, Al-Haiqi A. Development of a mobile game application to boost students' motivation in learning English vocabulary. IEEE Access. 2019;7:13326-37.

[19] Khan T, Johnston K, Ophoff J. The impact of an augmented reality application on the learning motivation of students. Adv Human-Computer Interact. 2019;2019.

[20] Shanmugam L, Yassin SF, Khalid F. Enhancing students' motivation to learn computational thinking through mobile application development module (M-CT). Int $\mathrm{J}$ Eng Adv Technol. 2019;8(5):1293-303.

[21] Sofia N, Mubarok H. The Impact of English game-Based Mobile Application on Students' Reading Achievement and Learning Motivation. Int J Instr. 2020;13(3):247-58.

[22] Ferreira MJ, Moreira F, Pereira CS, Durão N. The Role of Mobile Technologies in the Teaching / 
Learning Process Improvement in Portugal. 8th Annu Int Conf Educ Res Innov (ICERI 2015) [Internet]. 2015;(16th-18th November 2015):4600-10. Available from: http://repositorio.uportu.pt/bitstream/11328/1352/1/ICERI_2015_2150_vFinal.pdf

[23] Hwang GJ, Wu PH. Applications, impacts, and trends of mobile technology-enhanced learning: A review of 2008-2012 publications in selected SSCI journals. Int J Mob Learn Organ. 2014;8(2):8395.

[24] Blackwell C. TEACHER PRACTICES WITH MOBILE TECHNOLOGY INTEGRATING TABLET COMPUTERS INTO ...: EBSCOhost. J Educ Res [Internet]. 2013;7(4):231-55. Available from: http://web.a.ebscohost.com.libproxy.unitec.ac.nz/ehost/detail/detail?vid=87\&sid=ca33f7fc$6 \mathrm{e} 2 \mathrm{f}-4944-810 \mathrm{~d}-$

41d576d28640\%40sessionmgr4009\&hid=4106\&bdata=JnNpdGU9ZWhvc3QtbG12ZSZzY29wZT1z aXRl\#AN=95761851\&db=ehh 